\title{
Destabilising Notions of the Unfamiliar in Australian Documentary Theatre: version 1.0's CMI (A Certain Maritime Incident)
}

\section{Ulrike Garde, Macquarie University}

In 2004 the ensemble of artists version 1.0 staged A Certain Maritime Incident $(C M I)^{1}$ in Sydney. This show about asylum seekers arriving by boat successfully challenged notions of the unfamiliar, that is perceived by audiences as different, foreign or insufficiently known ${ }^{2}$ : Rather than (re)presenting 'boat people' as strangers, it invited audiences to discover the unfamiliar sides of the self and within their own culture through an effective use of destabilisation strategies which opened up new spaces of meaning.

In order to emphasise that what is regarded as 'familiar' and 'unfamiliar' within and between cultures and subjects is not a fixed entity, but rather the result of processes of mutual positioning during encounters (Gutjahr 2010: 26), this analysis employs the term 'unfamiliar' rather than 'stranger'3 and applies it to performance analysis. This term, inspired by the word 'fremd' used in intercultural German Studies (Albrecht 2003) is well suited to engage with reflections about a world which is marked by our intercultural condition (Leggewie \& Zifonun 2010: 14) and its associated flexibility and

\footnotetext{
${ }^{1}$ Performance created and performed by: Danielle Antaki, Stephen Klinder, Nikki Heywood, Deborah Pollard, Christopher Ryan, David Williams; lighting and production: Simon Wise; video and design: Sam James; dramaturge: Paul Dwyer; sound design: Jason Sweeney. Performance Space, Sydney, 26 March11 April 2004 (version 1.0 2004a). In 2006, Australasian Drama Studies published the script or performance text, referred to in this article as 'Script'; it has since been republished in version 1.0's collection Remixing Politics (2012).

${ }^{2}$ These meanings largely reflect the polysemic German word fremd; see Albrecht (2003: 234, 237).

${ }^{3}$ These considerations are part of a larger project I am currently undertaking together with Meg Mumford; it focuses on 'Reality Theatre and the Arts of Encountering the Unfamiliar.'
} 
uncertainties. The ability to refer to an unknown person as 'unfamiliar' can also be considered as an invitation 'to conduct dialogue about the relevant differences' (Appadurai 2009) between people, rather than labelling possible dialogue partners as 'strange' in their entirety, with the connotation of being 'odd,' and as 'strangers.' Having the capacity to disrupt perceptions that fix asylum seekers in potentially oppressive ways seems all the more important in the current context of rising asylum claims as reported by the UNHCR. ${ }^{4}$ This report with its global focus shows Australia as one among many countries that needs to meet the challenges of an increased influx of these new arrivals. ${ }^{5}$

In Australia the arrival by boat of people who intend to seek asylum has been a hotly debated issue; considerable media attention to such arrivals is not only at the centre of version 1.0's 2004 performance, but has continued to provoke Australia's citizens and politicians. At the time of publication of this article, the country has seen several alterations of related policy; the change of policy brought about by a change of government under former Labor Prime Minister Kevin Rudd in 2007 has since been revoked. The new approach, the so-called Pacific Solution II, where refugees are transferred to countries outside of Australia while their applications are being assessed, has been put into place. The relevant website of the Parliament of Australia states that 'With the rise of unauthorised boat arrivals in Australian waters since 2008, dealing with asylum seekers is once again a major political issue in Australia, as it was during the [Liberal] Howard Government [1996-2007]' (Phillips 2012: 9).

The Australian Broadcasting Corporation (ABC) marked the tenth anniversary of '[w]hen Australia stopped the refugee boats in 2001' with a documentary entitled Leaky Boat (Midwinter Pitt 2011). This program, together with Go Back to Where You Have Come from (O’Mahoney 2011), ${ }^{6}$ has made an important contribution to Australia's

\footnotetext{
${ }^{4}$ UNHCR figures show 'that new conflicts and a rising outflow from older crisis spots such as Afghanistan together contributed to a 20 per cent rise in asylum claims in industrialized countries in $2011^{\prime}$ (2012).

${ }^{5}$ Within the European Union (EU), the so-called Dublin regulation comes to mind, an EU Law that forces asylum seekers to remain in the first European country they enter (Grant \& Domokos 2011).

${ }^{6}$ In the same year, Australia's SBS (Special Broadcasting Service) aired the three-part reality television series Go back to Where You Have Come from (O’Mahoney 2011). However, due to its different format and focus, the series is not immediately relevant for discussing how Australian documentary theatre has addressed the question of the unfamiliar in the context of a 'Certain Maritime Incident.'
} 
communicative memory ${ }^{7}$ ten years after the Norwegian freighter MV Tampa rescued Afghan asylum seekers and was refused entry into Australian waters (August 2001), and the subsequent 'children overboard affair' (October 2001) and the SIEV X incident in the same month. In the children overboard affair, which occurred during an Australian federal election campaign, the Australian Government falsely accused sea-faring refugees on the SIEV 4 of having thrown their children overboard in order to coerce maritime rescue and to gain asylum. Shortly after, in a subsequent maritime disaster, over 300 people from the SIEV X, a brittle Indonesian fishing boat, perished. While both $\mathrm{ABC}$ documentaries aimed at generating a better understanding of the unfamiliar asylum seekers, whose individual fates seem to disappear behind the numbered acronyms of SIEV (Suspected Illegal Entry Vessels) and at modifying Australians' attitude towards them, they largely continued a long tradition of opposing the familiar culture(s) of Australians and the unfamiliar culture(s) of the 'boat people.'

This tendency is also apparent in much so-called migration or refugee theatre, including many performances during 'an extraordinary resurgence of political theatre [in Australia], from 1999 to 2005, produced in response to the Liberal Government's policies of detainment and forced deportation of asylum-seeking refugees' (McCallum 2009: 298). These performances included Mamouney's Citizen X (2002), Jamieson's In our Name (2004) and Horin's Through the Wire (2005). ${ }^{8}$

By contrast, the Sydney-based ensemble of artists version 1.0 used an innovative approach $^{9}$ and decided not (re)present the 'boat people' as strangers in their production CMI; instead it offered Australian audiences an opportunity to see the unfamiliar in themselves rather than in those frequently rejected as 'the other.' This might be one of the reasons why critical engagement with $C M I$ has not ceased since; it seems as though

\footnotetext{
${ }^{7}$ Jan Assmann defines communicative memory as referring to a recent past. Unlike cultural memory, it has not been formalised or institutionalised and is thus more fluid and malleable (2008: 112-13).

${ }^{8}$ For detailed information about the 'politics of exclusion' in response to asylum seekers and the resurgence of "various forms of documentary theatre engaging with the plight of asylum seekers in Australia,' see Hazou (2011: 5-7).

${ }^{9}$ The ensemble of artists defines itself as practitioners who 'engage with significant political and social issues using innovative theatrical strategies' ('Version1.0: Innovative Political Performance' 2012). Version 1.0 was founded in 1998 and granted Key Organization status by the Theatre Board of the Australia Council in 2009. In recent years they have engaged with various political topics, among them The Wages of Spin (2005) as an examination 'of the issues at the core of the controversy surrounding the "intelligence" reports that were the deciding factor in Australia's involvement in the war in Iraq,' and Deeply Offensive and Utterly Untrue (2007-2009), which investigated an inquiry into an Oil-for-Food Program in the context of Australian involvement in the war in Iraq.
} 
many researchers, including myself, have been trying to explain the performances' strong impact. In the context of past academic writing about $C M I$, my article is written with the purpose of acknowledging the ongoing relevance of this work, and analysing its aesthetic approach and effects.

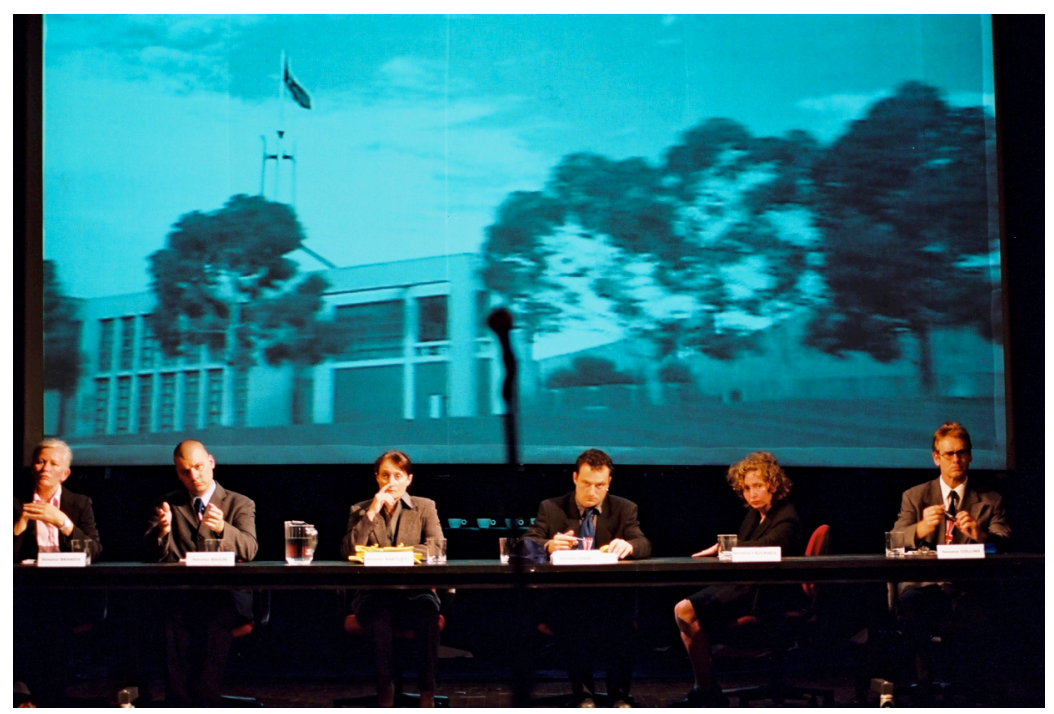

Figure 1: version 1.0's CMI. Photo by Heidrun Löhr

Not only did the theatre performance $C M I$ offer information, it also allowed audiences to intimate, in however brief and tenuous a manner, the unbearable, unspeakable and unrepresentable dimension of the 2001 traumatic events. The following analysis will show how, through a destabilisation of meaning, a playful inversion of socio-political responsibilities and a creative approach that challenges common notions of the roles of fact and fiction, version 1.0 created highly effective, politically engaged documentary theatre which challenged traditional notions of the unfamiliar in the "children overboard affair.'

In the context of a world marked by the proliferation of cultural diversity, increased human mobility and a growing number of refugees, the production explored two main aspects of the 'unfamiliar' as a mode of viewing and positioning oneself by interweaving two stories and issues. Firstly, the so-called boat people represented the 'unknown' and possibly the 'strange' often associated with the outsider and the foreigner, including in connection with Australia's 'ancient fears about boat people' (Marr 2009). Secondly, the performance also focused on the events and related trauma of the subsequent maritime disaster of the SIEV X. Here, a fictionalised version of verbatim passages facilitated access to the unspeakable and unrepresentable. The 
performance also engaged with the unfamiliar within Australia's 'own' culture by addressing audiences' potential feelings of individual and collective shame, anger, dismay, and sorrow, thus offering a public forum for experiencing potentially suppressed feelings and for renegotiating communicative memory.

\section{Destabilising notions of fact, truth and fiction}

With the above aims in mind, the artists used elements from tribunal and verbatim theatre in order to revisit a 2002 Senate Select Committee which investigated claims that the Australian Government had lied to the public over the 'children overboard' affair in the lead up to the 2001 election. It was derived from 'the actual words' taken from the transcripts of the committee and related media reports; David Williams, producer and performer, stresses the importance of the project's 'verbatim-ness,' 'both politically and artistically' (Williams 2006: 125). Rather than being based on interviews undertaken by version 1.0, as in 'classic' verbatim theatre, ${ }^{10}$ the dialogues presented on stage in four acts comprise a selection of speech acts and narrative structures already provided by the 56 witnesses in the inquiry and the related 2,200 pages of documents, produced during the 15 days of the Senate hearings. These 'real people' from the Senate, the public service, and the navy then appear as characters on stage with the actors switching between performance and personae. However, it is important that $C M I$ shows neither embodiments of refugees nor does it comment directly on any of the actions it (re)presents.

The artists reframe the original inquiry making strategic use of the verbatim passages in the context of a new, staged inquiry in order to explore 'the 'children overboard' lies, the real tragedy of SIEV-X, border panic hysteria, and the failure of the political process, thereby proposing fundamental questions at the intersection between the personal and the political' 'version1.0: Innovative Political Performance' 2012). The theatricality or 'theatrics' already present in politics and the media (see Script 2004: 13) is used effectively to create a performance of many voices that frequently comment or oppose each other, directly or indirectly, in an openly fictionalised inquiry revisiting the underlying truth-finding processes. In the performance script, 'the extra-daily

\footnotetext{
${ }^{10}$ For a taxonomy of verbatim theatre, particularly with respect to Australian theatre, see Wake (2010a: 6). Regarding the discussion whether CMI represented 'mock verbatim theatre,' see McCallum (2006: 138) and Young (2009: 81). See also Keith Gallasch's comment that it 'is not verbatim theatre but it is a performance devised from the transcripts of the Senate Select Committee Inquiry into the 'children overboard' scandal' (2004) and Webb (2009: n. p.).
} 
performance' and 'the everyday performance of ... public life' meet (Thompson \& Schechner 2004: 13), with the artists exploiting the performative nature of the speech acts claiming truth. To some extent they thus continue the international documentary theatre tradition, as represented for example by Peter Weiss' work, which set out to criticise the concealment, distortions, and lies of mass media (see Weiss 1971: 92). However version 1.0 stretch the documentary theatre mode much further by using a range of destabilising techniques which opens up new spaces for shifting meaning and audience perceptions, including conventional expectations with respect to fact, truth and fiction. As shown in the second part of this article, this aesthetic approach in turn destabilises notions of the unfamiliar.

The first destabilisation takes place when cracks appear in the facade of the truthfinding activities associated with the political inquiry; this dismantles the notion that a sense of authenticity, created by a return to the sources of the original words, might lead to veracity. As Susanne Knaller has pointed out, the 'authentic,' as a synonym of 'truthful,' 'unmediated,' and 'genuine, ${ }^{11}$ is constituted by a performative act and observation (Knaller \& Müller, 2005: 43, 45). It could be argued that it is based on a contract of authenticity between performers and spectators which has to be renewed for each 'authenticating act' (Garde 2013).

In $C M I$, however, the first scene with words in the prologue already challenges this contract, provoking the spectators to reconsider their understanding of authenticity and veracity as terms which they might consider as linked by cause and effect: against the background of an inverted Australian flag, a young boy, supported by an adult actor at his side, reads excerpts from statements which the Australian defence minister Mr Reith made shortly before the 2001 elections affirming that 'children were thrown into the water. $^{12}$

The performance contrasts the impression of a true and authentic - in the sense of original — speech act by the child with that of Mr Reith's political statement as a performative act, which merely obfuscated the truth in real life politics. To this aim, it strategically explores the interaction between the actor's body, language, and audience

\footnotetext{
${ }^{11}$ My translation.

${ }^{12}$ Script: 5; See also Trioli (2001). For an analysis of the scene in the context of false witnessing see Wake (2010b: 167).
} 
perception (see Fischer-Lichte 1995: 1-14; Metzger 2010: 11). On the one hand, the spectator witnesses a child who gives the impression of political innocence and whose pauses and intonation evoke the notion of an authentic delivery and of a genuine attempt to convey a message; the (non-invasive) lie detector consequently assesses his speech

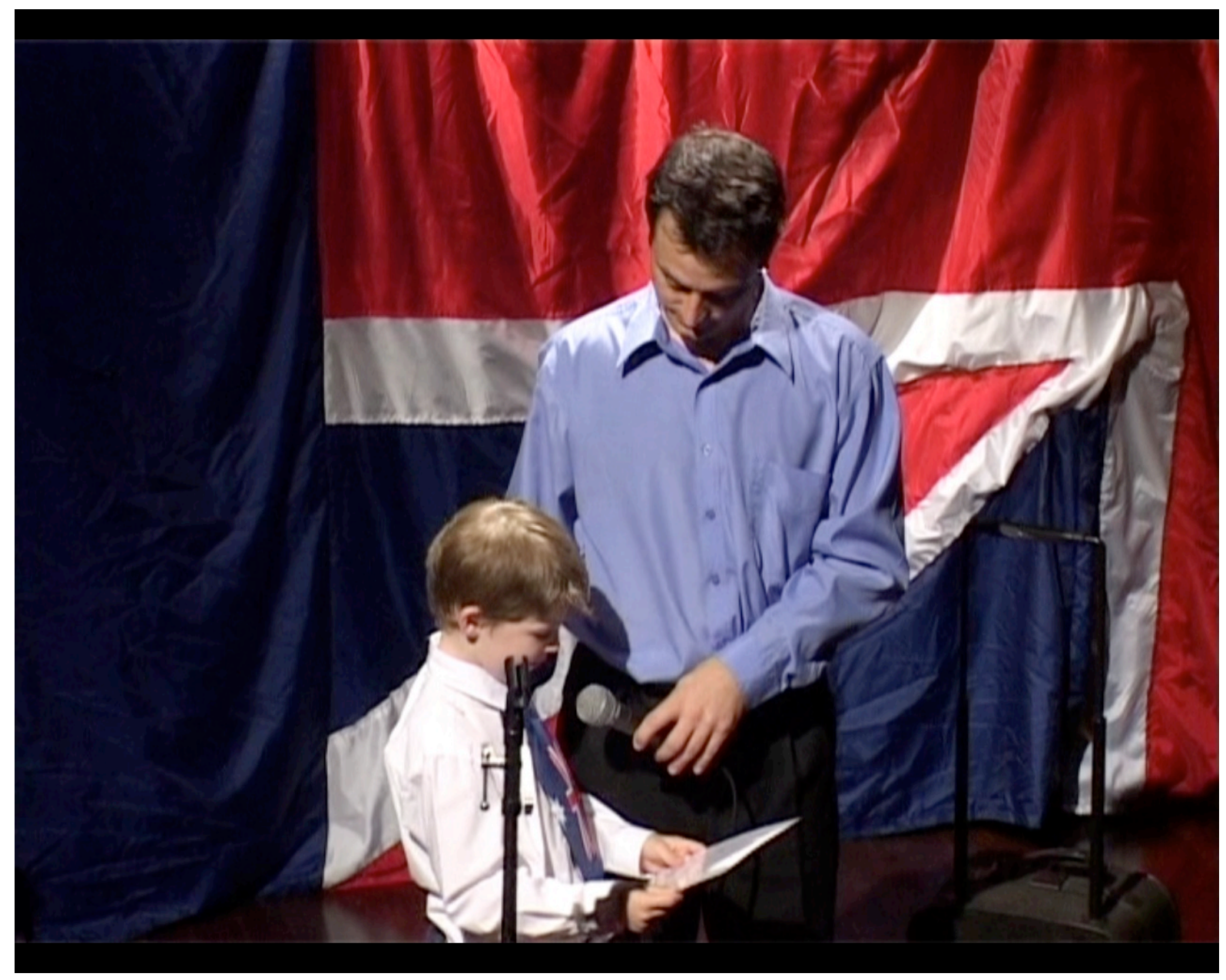

Figure 2: The child playing Mr Reith with Stephen Klinder as a guide/interviewer; still from the DVD (version 1.0 2004b).

act as "true. ${ }^{13}$ As a result of this fresh delivery of the speech, the audience perceives some of its contradictions as funny despite its serious repercussions. On the other hand, the adult performer's comment 'That was much better than you did last time' challenges the veracity of Reith's original political statement and mocks the lie detector's reliability. The audience is left to doubt whether 'authentic' speech acts exist and can be verified. This in turn raises the question whether any factual evidence can be obtained from the witness statements heard during the inquiry.

\footnotetext{
${ }^{13}$ McCallum (2006: 139) points out the irony "that the software almost always returns a "truth" reading for actors performing texts, because they are not, of course, actually lying.'
} 
As the performance evolves, the perceived power of facts is gradually being dismantled thus illustrating Derek Paget's observation that 'neither documents nor facts can or should be equalled with a positivistic kind of truth' (1998: 101-5). At the same time $C M I$ reveals fiction as a strong force whose power initially becomes apparent when language that has been originally used in political statements or as part of the Senate hearings loses its referential function in the context of a theatre performance, taking on a poetic function instead.

For example the child's performance described above emphasises the three adverbial clauses which delay and modify the message of the sentence 'these photos show absolutely without question whatsoever that there were children in the water' (Script: 4). While a tricolon in a political speech might serve its rhetorical purpose, in a performative context, this gradual shift of meaning in time and space evokes Derrida's différance (1972: 1-30), which also shapes the performance on a larger scale, including the overall inquiry, based on the central question 'Were any children thrown overboard?' (Script: 11). The performance circles this question or circumnavigates it in an elliptical form ${ }^{14}$ producing new spaces for meaning in a playful manner as a result. Each time a witness attempts to answer the question the arguments appear more opaque and multi-layered. It becomes increasingly obvious that there were problems with 'the flow of information about the incident to the Federal Government, both at the time of the incident and subsequently' ('Terms of Reference' 2002). The spaces that are generated through the circular revisiting of the central question invite audiences to listen for what is not being said because it is being avoided or unspeakable.

As the performance progresses, the perceived boundaries between fact on the one hand and non-fact, speculation and fiction on the other hand become increasingly porous; this also applies to the term 'the fog of war,' which Vice Admiral David Shackleton originally employed to explain the strategic operations within the Navy. This expression regains its status as a quasi-poetic metaphor when reframed in the context of an artistic performance. As Hans-Thies Lehmann observed, the 'context of on-stage performance' together with 'the commonality of public reception' may lead to 'even modest thoughts' assuming great 'force and depth in the moment of theatrical performance' thus

\footnotetext{
${ }^{14}$ Derrida refers to an ellipse which illustrates that, while writing, he often notes the first definition of a concept sous rature (Spivak 1976: xiv). When Vice Admiral David Shackleton's statement is staged soon after the statement it is read from a beer coaster thus referring again to the leitmotif of the circle.
} 
surpassing themselves (Lehmann 2008a: 167-68). Accordingly, the following explanation, quoted by the second witness on the stage, acquires an almost philosophical depth and could be considered as a comment on the whole performance: '[The fog of war] is related to the reality that everything is real but it is not real' (Script: 7). ${ }^{15}$ Spoken originally in the context of the 'children-overboard' inquiry and the related failure of clear communication, the statement almost seems cynical when restaged in the context of a theatre performance. Yet, its meaning shifts again, developing the quality of a nightmare, when taking into account that the entire performance is set against the background of the later maritime disaster of the SIEV X. The audience is clearly aware of this as it has been provided with a time line of events displayed on an overhead projector early on in Act I.

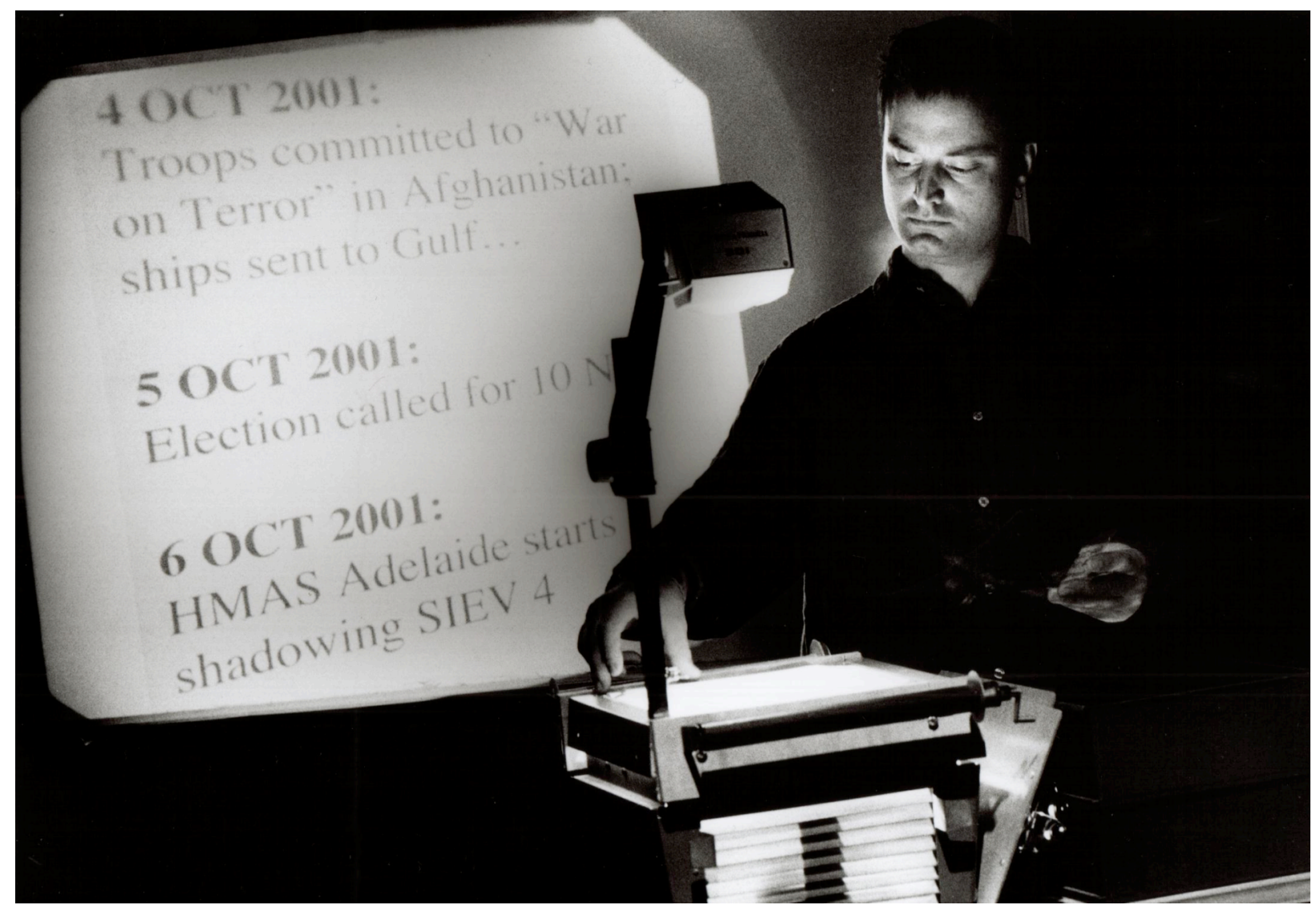

Figure 3: Stephen Klinder. Photo by Heidrun Löhr.

This gradual erosion of the perceived power of facts and documents as providing access to or proof of 'truth' puts into question any assumption that an examination of the Senate Inquiry's transcript will lead to clear insights into the 'children overboard affair.'

\footnotetext{
${ }^{15}$ For comprehensive analysis of the 'fog of war,' and its 'poetical' and political dimensions, see Williams (2006).
} 
The performance challenges audiences' potential belief in political processes by playfully inverting the expectation that the 'real' world rather than the arts would adhere to transmitting information 'faithfully' and 'correctly.,

This inversion is presented in a scene that develops the theme of circling meaning without ever getting to the centre, this time driven to the extreme of being out of control. The circling of meaning is visualised on stage by the senators' spinning black boardroom table on wheels, which almost covers the width of the stage. ${ }^{17}$ While the table is spinning the character Commander Banks - in charge of HMAS Adelaide when it intercepted the Indonesian vessel at sea- has to run to the microphone to complete his witness statement as follows: 'In summary, by 10 October, it was clear ... that no children had been thrown overboard, and that no signal originating form HMAS Adelaide had ever referred to an incident involving children being thrown overboard. Thank you Senators' (Script: 16). In the background a traditional black and white overhead projector presentation comments on the action as follows: 'NO TABLES WERE SPUN DURING THE CMI INQUIRY. / EXCEPT PERHAPS THE TEA TROLLEY. / BUT THIS IS SPECULATION NOT FACT’ (Script: 16). ${ }^{18}$

This scene uses the tension between 'real' events, 'real' words and the search for truth to show that in a Senate inquiry, which focused on every single detail of the incident and related reports, the most important point of investigation had nearly been pushed from the centre of attention, thus creating an almost grotesque quest for an unattainable truth. From there, it is a small step to the question of whether any tables were spun during the inquiry, a question which serves to illustrate an inversion of political ethics and responsibilities: while one might commonly expect the inquiry to produce a 'truth' based on facts, ${ }^{19}$ the transcript contains many half-lies, speculations, and avoidance tactics, which ultimately do not clarify the 'real' events, actions, and reactions by the

\footnotetext{
${ }^{16}$ Jen Webb (2009) points out that CMI reminds audiences 'that something outrageous has been perpetrated, and that it was not taken seriously by those in authority.'

${ }^{17}$ Trezise (2004) makes the following comparison: It 'spins in the space like a ship giddily changing course. The table lurches alongside the linguistic rhythms of a political charade that is decontextualised and now exists in "quotation marks."

${ }^{18}$ In $C M I$ all overhead transparencies are written in capital letters.

19 'At issue, for the Committee, was the question of why none of the three most senior officers in the Australian Defence Organisation considered himself to be in a position to provide serious and robust advice to the government in relation to the truth of the original report that children had been thrown overboard, or in relation to the need for the correction of the public record in relation to the photographs' ('Executive Summary’ 2002).
} 
people meant to be in charge. In contrast, the theatre performance that, as art, might be spontaneously associated with free invention and speculation, works with accurate information, including a seemingly ridiculous statement, in order to avoid distorting the facts. After all, the overhead remark about the spinning table represents one of the few entirely honest and straightforward comments presented on stage.

The overhead also reflects broader feelings of frustration due to the lack of information and insight at the time. On a practical level, this is caused by insufficient access to documentation: At the time of the actual incident what actually happened out at sea remained to some degree speculation; it could not be (dis)proven with 100 percent accuracy on the basis of imprecise film material, even though Mr Reith declared it to be 'absolute fact' in the original statement quoted on stage (Script: 5); as is characteristic for speculation, the events on the SIEV 4 and SIEV X exceeded common experience and insight, due to limited access to the original boats, to the information available to those involved and due to the monstrosity of events related to the maritime disaster of the SIEV X. Consequently, this inversion strikes further at the foundations of the categories of fact and truth creating a new frame for assessing the flow of information in the 'children overboard' affair. Accordingly, the performance presents a world (both on and off stage) whose underlying socio-political causes and effects can no longer be deduced and exposed in a Brechtian manner as an accessible one (Brecht 1993: 555). Despite its tongue-in-cheek allusion to Brecht's Verfremdung, based on dated technology (Dwyer 2006: 131-32), the political processes presented in CMI are rather based on a world view, similar to Friedrich Dürrenmatt's, where the state cannot be envisioned because of its bureaucratic structures and because ' $[\mathrm{t}]$ here are no true representatives' who can be made accountable. In this world, people's misfortune seems too vast, too complex, and too horrible to be conveyed via traditional tragedy; Dürrenmatt (1982: 252-56), for instance, advocates the grotesque instead. ${ }^{20}$ The grotesque as a variation of Verfremdung or defamiliarisation ${ }^{21}$ is evident in CMI when 'Mr Reith's scene' is played out in front of an inverted Australian flag, when board

\footnotetext{
${ }^{20}$ With reference to Freud, Jestrovic describes the grotesque as not offering 'the comfort of a rational explanation of the uncanny with which to restore traditional order' (2006: 86).

${ }^{21}$ I choose the term 'defamiliarisation' as it mirrors an aspect of the original term Verfremdung, which is important for the focus of my analysis. As Mumford has pointed out there is a range of English translations 'each of which alludes to a relevant feature of this concept [Verfremdung]' (2003: 1404). My emphasis is on making a phenomenon seem unfamiliar rather than 'strange' and which might remind the reader of 'alienation'; see 'estrange' (2005).
} 
room tables spin, a witness runs to deliver the 'truth' and factual truth can be found in grotesquely blown up factual details on stage.

On another level the insistence on accurate modes of communication within the performance also alludes to version 1.0's everyday democratic model of performance making, thus providing it with some authority to cast a critical eye on socio-political processes. This democratic approach also becomes apparent in another comment on an overhead transparency, which states: 'THE ACTORS DID NOT UNANIMOUSLY AGREE WITH THE STAGING OF THIS SCENE. THEY USE A DEMOCRATIC MODEL TO CREATE THEATRE AND COMPROMISE IS A WORKING SOLUTION' (Script: 33).

At the same time, this comment foregrounds the artistic processes involved in making $C M I$; such a self-reflexive performance encourages audiences to 'adopt an actively critical perspective on the events [and statements]' shown on stage (Bottoms 2006: 61). This active audience involvement not only invites audiences to deal with the destabilisation of common notions of facts and truths, but it also prepares them for a critical reflection of their concepts of and attitudes towards the unfamiliar.

\section{Destabilising audiences' notions of the unfamiliar}

$C M I$ differs from most so-called migration or refugee theatre in its move away from an emphasis on the migrant or asylum seeker as the unfamiliar outsider to a focus on the unfamiliar within one's own-here the Australian — culture. In William's words, it is 'much more concerned with "us" than "them"' (2006: 126). Although initially the verbatim passages still convey the frequent use of stereotypes in political and media utterances of the time, apparent in quotes such as 'the behaviour of these people [on the boat]' versus 'our culture and our values' (Script: 21, 20), these are soon mocked in a self-reflexive manner. In one of the open additions to the original words spoken at the inquiry, the artists refer to Australia's pride in its sporting achievements in order to stress how even the ability to swim — for the refugees a matter of survival — could be easily assessed as a marker of cultural identity. Accordingly, the CHAIR comments on their poor swimming skills as follows: 'It is one of the cultural differences, for God's sake. [Didn't you see the last Olympics?].' This quote, together with the added 
humorous remark in brackets (Script: 27), ${ }^{22}$ indirectly criticises the public debate for its tendency to ignore that any definition of cultural identity consists of mutually attributed markers rather than of inherent or stable characteristics. Version 1.0's work thus corresponds to that of other theatre practitioners inspired by verbatim theatre, such as Moisés Kaufman, who reinforce the idea of identity as a construct (Svich 2003). ${ }^{23}$

At the same time, the CHAIR's remark represents one of the many instances throughout the performance where statements from the Senate hearing are verfremdet: what might be expected to be familiar as part of one's own culture becomes unfamiliar and strange. This encounter with the unfamiliar in turn might make audiences wonder whether their own behaviour can be considered any longer as 'natural' and acceptable. ${ }^{24}$ Indeed, the performance's central issue consists, in David Williams's words, of the 'disturbing question of what it meant that the lie [of the 'children overboard' affair] was so easily accepted by so many without the need for substantiation' (2006: 123). In retrospect, some audience members might perceive their own 'easy acceptance' as unfamiliar, strange, and out of character, particularly in the context of Australia as a country that claims a tradition of 'mateship' as part of its value system. ${ }^{25}$ When allowing for these potential feelings of individual and collective shame and guilt, $C M I$ fulfils two functions. First, it provides audience members with an opportunity for increased self-awareness and a possibility to experience new aspects of themselves (see Lehmann 2008b: 21-22). Second, the live theatre performance represents an opportunity to publicly renegotiate communicative memory where remembering becomes 'crucial to testimony, accusation and trauma management' (Thompson \& Schechner 2004: 15; Webb 2009). Both functions are evident in several reviews, such as when Bryoni Trezise asks in her article for Real Time (2004) '[H]ow — and who — are we to engage in a performance of the national shame in which we are all to some degree complicit?'

\footnotetext{
22 This is followed by the remark 'That was not in the transcript.' In the original Hansard transcript ('Official Committee Hansard' 2002), the discussion about the ability to swim centred on refugees from Afghanistan and Iraq.

${ }^{23}$ Kaufmann also openly shows how a performance represents 'a construct of a certain reality' (Svich 2003: 71-72). See the related analysis of Kaufman's work in Bottoms (2006: 61-67). See also Hall (2003: 1-17).

${ }^{24}$ For the epistemic value of experiencing the unfamiliar, see Waldenfels (1998: 43).

${ }^{25}$ Carroll (1995: 4) refers to 'the "mateship" or brotherhood of working men' as 'an especially hallowed relationship.' A reference to 'mateship' was included in the 2007 booklet that prepared applicants for the Australian citizenship test; see Commonwealth of Australia (2007: 7).
} 
A seemingly humorous comment shown early in the performance on the overhead projector indirectly assists this collective examination of one's own behaviour. It reads:

\author{
WE KNOW THAT YOU KNOW \\ WE ARE NOT REALLY THE SENATORS \\ WHO TOOK PART IN THE CMI SENATE INQUIRY. \\ STEPHEN IS A LOT SHORTER THAN SENATOR COOK \\ AND DEBORAH WHO PLAYS SENATOR FAULKNER IS ACTUALLY A WOMAN. \\ WE FOUND THAT OUT AFTER THE AUDITION. (Script: 9)
}

While the joke-like use of punch lines might add some comic relief to the performance, the text in its deeper meaning extends beyond a self-reflexive comment on representational performance modes in a documentary performance where actors switch easily between playing characters and personae. Its significance for the traumatic events involving the asylum seekers on the SIEV X consists of the phrase 'we know that you know' and its ability to create, early in Act I, an atmosphere of complicity of knowing and finding out. It involves theatre practitioners and audiences and sets the tone for the following collective re-examination of the inquiry described in this article. Accordingly, the critic John McCallum had the impression that the performance generated an 'affective community' (McCallum 2006: 141). As Helen Gilbert and Jacqueline Lo have argued (2007: 203), CMI's significance resides at least partly in eliciting 'shame and outrage as a prelude to ethical community.'

As a community audiences are also exposed to the traumatic experiences, both with and without words. Initially the perspective of the SIEV X victims remains wordless unlike in the 'classical' documentary play, where alternative points of view are often introduced via a 'double reconstruction' of past events (Friedrich 2000: 289). The silence and absence of bodies directly representing the refugees results in a presence of absence which is particularly noticeable in the performance's frame: in the beginning, the spectators need to step over naked tagged bodies lying on the floor, evoking the corpses of drowned asylum-seekers, in order to get to their seats. ${ }^{26}$

As Yana Taylor, outside eye in $C M I$, stated, the theatre practitioners avoid speaking for the absent refugees feeling that,

\footnotetext{
${ }^{26}$ Despite the many elements of black comedy in the show, this opening frame sets a tone that lingers in the background of the entire performance so that the direct engagement with the suffering of the SIEV X passengers has been positively received in many articles; however, Webb (2009) has voiced some criticism of the performance's tone and mood.
} 
[a]s artists, we would dishonour people who sought asylum by arriving on boats by acting in their role in our bodies. [Instead] we chart the parameters of their exclusion, their absence from the Senate's inquiry. And by this, we point to the machinery of governmental power that excised understanding of their position, needs and future from public discourse at the time. ${ }^{27}$

Instead of being embodied on stage, the voices of the SIEV X's victims seem to lurk in the spaces and cracks which version 1.0 deliberately creates in the performance text through destabilising meaning thus successfully negotiating the 'challenge of finding ways to engage with Others whose presence at the border of the nation has been marked by both hypervisibility and invisibility' (Gilbert \& Lo 2007: 189).

While the tone of this opening frame lingers in the background of the entire performance in contrast with its many elements of black comedy the performance's final scene begins with an open shift in mood that also signals a different approach to the victims' stories because it offers some access to the survivors' perspective. ${ }^{28}$ It is particularly powerful because it uses fiction as a tool whose function Wolfgang Iser has described as follows: '[T] he fictive compels the imaginary to take on a form at the same time that it acts as a medium for its manifestation' (Iser 1993: xviii). He concludes that the 'fictionalising act' ultimately 'endows the imaginary with an articulate gestalt - a gestalt that differs from the fantasies, projections, daydreams and other reveries that ordinarily give the imaginary expression in our day-to-day experience' (1993: 3). In the case of $C M I$, the imaginary includes the unspeakable and the unrepresentable dimensions of the traumatic events.

In the entire last scene audiences encounter yet another variation of the unfamiliar by being exposed to the traumatic events at sea in a vastly different way from the associated media reports, when a computerised voice reads witness statements from some of the 44 survivors of the SIEVX disaster, accompanied by a projection of the text, which flashes like subtitles across the large screen at the back of the stage. The performance undermines the perception of the human voice as a human being's

\footnotetext{
${ }^{27}$ Personal interview with Ulrike Garde, 18 March 2009. The dramaturge Paul Dwyer (2004) stated: 'This is not a show about the behaviour of, or to explain the point of view of, asylum seekers. We do, however, focus on various representations of asylum seekers that were produced during the course of the inquiry.' See also Dwyer (2006: 134). This decision prevents creating a 'sense of objectification of the immigrant as an exotic Other,' a criticism voiced in Jestrovic's analysis of Antonio Miro's 2007 Barcelona fashion show (2008: 162).

${ }^{28}$ For more reviewers' responses illustrating the impact, see: McCallum (2004); Meston (2004); and Trezise (2004). Webb (2009) offers a more critical assessment of the last scene as 'a last-minute acknowledgement of the genuine suffering of the SIEV X passengers' while Burvill refers to the opening and the closing scene as 'two passages of performance which had essentially a metaphorical and poetic mode of interpellating the spectator' (2008: 239).
} 
'genuine' and 'unmediated' 'way of expressing him- or herself' (Kolesch 2005: 214) ${ }^{29}$ by emphasising technology and disembodiment, and by combining several stories in a testimony where one account overlaps and merges with another. While parallel to the screen a male actor's body is prepared for the mortuary, audiences listen to and read the text which comprises accounts of the makeshift overcrowded boat, of the merciless struggle to survive when it begins to sink and of loved ones drowning. On the surface, the text is very factual consisting predominantly of main clauses and containing hardly any adjectives. Apart from 'weeping' and 'crying,' emotional reactions to the events are only expressed indirectly through references to actions rather than to feelings. In the performance, the survivors' account is verbatim in nature but has been fictionalised through acts of selection, combination (Iser 1993: 222-38) and aesthetic reframing. The aesthetic dimension becomes obvious to audiences when the text is projected onto the large screen showing a blue open sea with moderate waves and read by the computerised voice with 'throbbing, sometimes distorted sometimes harrowing soundscape' (Meston 2004). In this reframed context the text shares a key characteristic

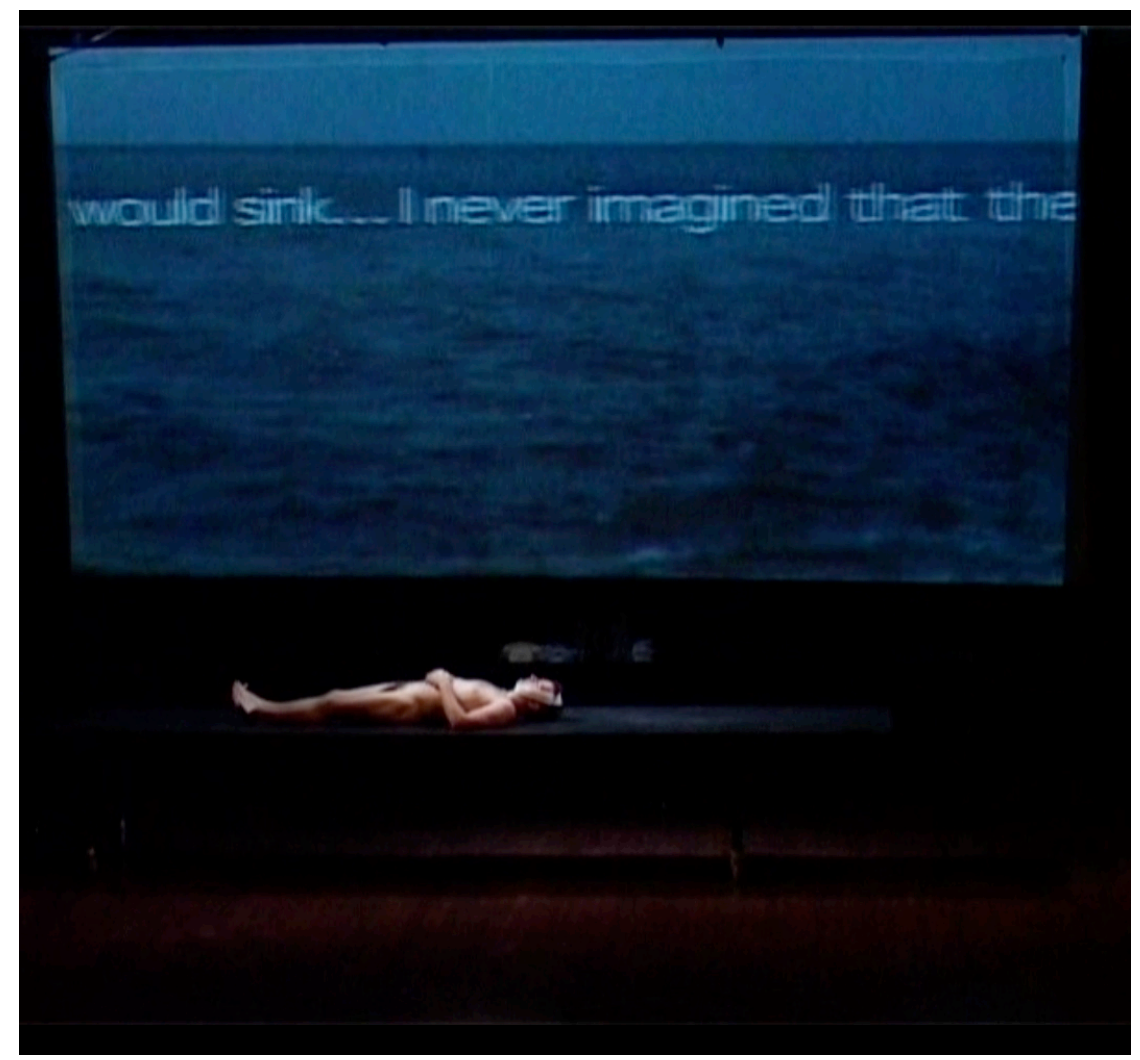

Figure 4: Stephen Klinder; still from the DVD (version 1.0 2004b).

\footnotetext{
${ }^{29}$ The statements quote from a 'videotape that was made of the survivors of the SIEVX disaster at Bogor in the week following the shipwreck. It was translated by Keysar Trad of the Lebanese Muslim Association, Sydney' (SIEVX Survivor Accounts 2002). See also McCallum (2006: 140).
} 
with fiction, in that it contains many 'blanks' (Iser 2006: 64) that spectators need to fill imaginatively with meaning. ${ }^{30}$ Audiences play an active role in projecting a personal version of the events onto the blue screen with the sea at the back of the stage. Their active involvement becomes even clearer in the text's last sentence, where the computerised voice repeats the original sentence 'I never imagined that the boat would sink' seven times.

By combining repetition with the gradual introduction of blanks or empty spaces the performance 'bring[s] to light the unthinkable and the unrepresentable or unspeakable' (Gampel 2000: 49); once again fiction serves as a medium for offering a glimpse of the account's traumatic dimension. ${ }^{31}$ The repetitions not only evoke the symbolically charged number and the re-experience of traumatic events in flashbacks, by using the past tense they also emphasise the lost hope that the boat would provide a safe passage to a place of refuge. Consequently, the sentence indirectly accuses both the people smugglers, who provided the unsafe vessels, and the current state of global responses to refugee crises, including that of Australia. On the emotional level, the statement relegates the capacity to hope to the past, thus emphasising the survivors' current state of despair. ${ }^{32}$ This desolation is reinforced when, towards the end of the spoken text, the reader inserts a pause between 'I never imagined' and the remainder of the sentence, which is followed by the final incomplete repetition, 'I never imagined ...' (Script: 43). What happened cannot be expressed in a factual mode; this aligns with Slavoj Žižek's description of the real: '[P]recisely because it is real, that is, on account of its traumatic / excessive character, we are unable to integrate it into (what we experience as) our reality, and are therefore compelled to experience it as a nightmarish apparition' (2002: 19). Žižek's real recalls the imaginary as deployed in Iser's approach in so far as it needs to be mediated via fiction. Hence Žižek states that we are only able to sustain the real 'if we fictionalise it' (2002: 19).

This power of fictionalisation is reinforced through the juxtaposition of the written text on screen, which is simultaneously read out aloud, 'and the corporeal body of the performer positioned onstage as a corpse and a symbolic reminder of the drowned

\footnotetext{
${ }^{30}$ Lehmann has shown that 'this aspect of "concretisation" of meaning' applies as much to the act of spectating as it does to the act of reading (1999: 191).

${ }^{31}$ For a further discussion of trauma, see Weller (2007: 160).

${ }^{32}$ Stephen Castles (2011) called the 'deprivation of hope' 'one of the greatest problems' in the context of asylum seekers, refugees and internally displaced persons.
} 
bodies of the asylum seekers.' As Radan Hazou argues, this hypermediacy 'works both to expose and engage the audience's desire for immediacy' and to gain direct contact 'with an asylum seeker's story' (2011: 18). The resulting sense of 'authenticity' (Hazou: 18) can be partly attributed to the effects of the hypermediacy, but it is also due to the effective use of fiction in $C M I$, which allows audiences to intimate, however briefly and tenuously, the unbearable, unspeakable and unrepresentable dimension of the 2001 events. Rather than appropriating and representing the unfamiliar voice or fate it provides audiences with the freedom to respond to the accounts with their own, personal images and interpretation of the disaster. As Nickel-Bacon, Groeben and Schreier have pointed out, "when it comes to the ... reception of fiction, communicators derealise their own role: ... readers suspend their real selves and are ready to construct an imaginary world, even if individual aspects of that world clash with their own model of reality' (2000: 288). ${ }^{33}$ The openness of the personal responses also creates what Tom Burvill advocates as a 'space of indeterminacy' that stands 'against the closedness of the [actual] government's language' (2008: 241). At the same time, CMI shifts audiences' perceptions through creating an awareness of the constructed nature of facts, truths, memory-making and of any preconceived ideas of the unfamiliar as a label for people, behaviour, and values, once again without providing definite answers to the questions raised and challenges presented. Several reviewers have expressed their appreciation of this openness and freedom resulting from the 'blanks' of fiction, stating 'the play doesn't seek to answer any of the questions that still surround the affair, nor does it attempt to draw any conclusions' (Nolan 2004). ${ }^{34}$ Consequently CMI does not strive 'to represent ... freedom but rather to generate and present it to everyone involved [in the performance], including and especially its audiences,' an approach that Erika FischerLichte (2005: 245) advocates as an effective way of political engagement in contemporary theatre. ${ }^{35}$

It could be argued that this openness also applies to the last scene as a whole because it transcends national borders by using the image of the open sea without references to Australian borders. Even when the performance returns briefly to the Senate Select Committee and to the associated Hansard transcript, it only comes to a preliminary

\footnotetext{
${ }^{33}$ My translation. See also Metzger (2010: 60).

${ }^{34}$ Meston (2004) agrees that '[i]t's not propaganda'; Alanna Maclean (2004) calls it 'a challenging, questioning piece.'

${ }^{35}$ Her emphasis. My translation.
} 
closure. Although the Chair, now embodied by the 'dead body' lying on the slab, pronounces the committee 'adjourned,' this very closure has just been rejected through the performance itself, which thus represents another variation of différance.

Consequently the performance seems to encourage an interpretation of the refugees' plight in a broader context of the increased global movement of people ${ }^{36}$ as expressed in one of the refugees' plea: 'I appeal to every person with humanity, I appeal to the Australian people' (Script: 41). In fact, the media image of the refugees' sinking boat has inspired other artistic work since ${ }^{37}$ and has invited audiences to engage on a broader scale with refugee stories, thus recognising 'the significance of the refugee' (Kushner 2006: 16) as an integral part of the history of the modern world.

In summary, $C M I$ has illustrated effectively that, in some cases, the playful and destabilising approach to 'facts' and 'truths,' together with a careful use of fiction in innovative documentary theatre achieves a greater degree of insight than an attempt to recreate a sense of authenticity and of closeness to reality and facts ${ }^{38}$ because it can lead to shifts in audience perception. If one agrees with Hans-Thies Lehmann that, currently, ' $[t]$ he politics of theatre is a politics of perception' (Lehmann 2006: 185; see also Webb 2009), then version 1.0's CMI provides an example of how these politics can be successfully applied. Towards the end of the program, the 2011 TV documentary Leaky Boat raises the question of how future generations will remember and judge our reactions towards the events of $2001 .^{39}$ By putting 'on the public record an alternative perspective on public events ${ }^{40}$ in 2004 CMI had already provided an answer, particularly because its elements of fiction uncovered the less obvious dimensions of the unfamiliar, that is the unfamiliar sides of the self and within our own culture.

\footnotetext{
${ }^{36}$ See United Nations Human Development Report (2009).

${ }^{37}$ SIEV X inspired other artistic works. A community-supported war memorial was built and a ceremony held in Canberra ('SIEV X Memorial' 2006). Paul Dean composed Abyss (Marriner 2009). The Berlinbased artist Dierk Schmidt painted Xenophobe-Shipwreck Scene, Dedicated to the 353 Drowned Asylum Seekers who Died on the Indian Ocean, on the Morning of October 19.

${ }^{38}$ For a discussion of closeness to the 'real,' see Young (2009: 86).

${ }^{39}$ In its summary, Leaky Boat refers to the memories and judgements of future generations, particularly with respect to the so-called Pacific Solution under which asylum seekers arriving by boat were transferred to offshore processing centres on Nauru and Manus Island.

${ }^{40} \mathrm{It}$ is noteworthy that since the script is readily available in print (version 1.02012 ), current and future generations are able to access version 1.0's perspective on these past events.
} 


\section{Reference List}

Albrecht, C. 2003, 'Fremdheit,' in Handbuch Interkulturelle Germanistik, (eds) A. Wierlacher \& A. Bogner. Metzler, Stuttgart: 232-38.

Appudurai, A. 2009, 'Beyond Multiculturalism?,' Opening Lecture for Beyond Multiculturalism? Fragen an die Einwanderungsgesellschaft, Haus der Kulturen, 4-6 Juni. Online, available: http://www.blog.hkw.de/ [Accessed 22 October 2010].

Assmann, J. 2008, 'Communicative and Cultural Memory,' in Cultural Memory Studies: An International and Interdisciplinary Handbook, (eds) A. Erll \& A. Nünning. Walter de Gruyter, Berlin \& New York: 109-18.

Barton, B. 1987, Das Dokumentartheater. Metzler, Stuttgart.

Bottoms, S. J. 2006, 'Putting the Document into Documentary: An Unwelcome Corrective?', TDR: The Drama Review, vol. 50, no. 3: 56-68.

Brecht, B. 1993, 'Über experimentelles Theater,' in Werke. Große Kommentierte Berliner und Frankfurter Ausgabe, (eds) W. Hecht, J. Knopf, W. Mittenzwei, \& K-D. Müller. AufbauVerlag/Suhrkamp, Berlin und Weimar/Frankfurt am Main: 540-57.

Burvill, T. 2008. 'Politics Begins as Ethics': Levinasian Ethics and Australian Performance Concerning Refugees,' Research in Drama Education, vol. 13, no. 2: 233-43.

Castles, S. 2011, 'Refugees, Asylum and the Global Order,' Keynote for Human Rights, Refugees and Asylum Seekers, Public Lecture organised by The Australian Sociological Association and Macquarie Centre for Research on Social Inclusion, 21 July.

Carroll, D. 1995, Australian Contemporary Drama. Currency, Sydney.

Commonwealth of Australia. 2007, Becoming an Australian Citizen. Citizenship. Your Commitment to Australia, Canberra.

Derrida, J. 1972, Marges de la Philosophie. Minuit, Paris.

Dreysse, M. \& Malzacher, F. (eds) 2007, Experten des Alltags. Das Theater von Rimini Protokoll. Alexander Verlag, Berlin. 2008, Experts of the Everyday. The Theatre of Rimini Protokoll. Alexander Verlag, Berlin.

Dürrenmatt, F. 1982, 'Problems of the Theater,' in Plays and Essays, (ed.) V. Sander. Continuum, New York: 231-62.

Dwyer, P. 2004, 'Tonight's Proceedings.' Program Note for CMI by version 1.0, Performance Space, Sydney, March. 2006, 'The Inner Lining of Political Discourse: Presenting the version 1.0 Remix of the "Senate Select Committee on a Certain Maritime Incident,"” Australasian Drama Studies, no. 48, April: $130-35$.

'Estrange.' 2005, The Macquarie Dictionary. Online, available: http://www.credoreference.com/entry/macqdict/estrange [Accessed 22 January 2013].

'Executive Summary.' Select Committee for an Inquiry into a Certain Maritime Incident. 2002. Online, available: http://www.aph.gov.au/SENATE/committee/maritime_incident_ctte/report/a06.htm [Accessed 22 October 2010].

Fischer-Lichte, E. 1995, 'Einleitung: Wahrnehmung, Körper, Sprache,' in TheaterAvantgarde. Wahrnehmung-Körper-Sprache, (ed.) E. Fischer-Lichte. Francke, Tübingen \& Basel: 1-14. 2005, 'Politisches Theater'in Metzler Lexikon Theatertheorie, (eds) E. Fischer-Lichte, D. Kolesch \& M. Warstat. Metzler, Stuttgart: 242-45.

Friedrich, H-E. 2000, “Datenschutt” und "Unsicherheitsrelation.” Die ästhetische Konstruktion von Wirklichkeit im Dokumentartheater (Hochhuth, Kipphardt, Weiss),' Zeitschrift für deutsche Philologie, vol. 119, no. 2: 268-89.

Gallasch, K. 2004, 'Children Overboard: Outrage and Performance,' RealTime, no. 59, February-March. Online, available: http://www.realtimearts.net/article/59/7365 [Accessed 14 January 2012].

Gampel, Y. 2000, 'Reflections on the Prevalence of the Uncanny in Social Violence,' in Cultures under Siege. Collective Violence and Trauma, (eds) A. C. G. M. Robben \& M. M. Suárez-Orozco. Cambridge University Press, Cambridge \& New York: 48-69.

Garde, U. 2013 [forthcoming], 'Reality and Realism in Contemporary German Theatre Performances,' in Realisms in Contemporary Culture: Theories, Politics and Medial Configurations, (eds) D. Birke \& S. Butter. De Gruyter, Berlin.

Gilbert, H. \& Lo, J. 2007, Performance and Cosmopolitics: Cross-Cultural Transactions in Australasia. Palgrave Macmillan, London.

Grant, H. \& Domokos, J. 2011, 'Dublin Regulation Leaves Asylum Seekers with Their Fingers Burnt,' The Guardian, 7 October. Online, available: http://www.guardian.co.uk/world/2011/oct/07/dublinregulation-european-asylum-seekers [Accessed 14 January 2012]. 
Gutjahr, O. 2010, 'Interkulturalität als Forschungsparadigma der Literaturwissenschaft. Von den Theoriedebatten zur Analyse kultureller Tiefensemantiken,' in Zwischen Provokation und Usurpation: Interkulturalität als (Un)vollendetes Projekt der Literatur- und Sprachwissenschaften, (eds) D. Heimböckel, I. Honnef-Becker, G. Mein \& H. Sieburg. Fink, München:17-39.

Hall, S. 2003, Questions of Cultural Identity. Sage, London.

Hazou, R. 2011. 'Intermedial Voices: Documentary Theatre and the Refugee Experience in Version 1.0's CMI (A Certain Maritime Incident),' Platform: Journal of Theatre and Performing Arts, vol. 6, no. 1. Online, available: http://www.rhul.ac.uk/dramaandtheatre/platform/issues/vol6-no1spectatorshipandparticipation-autumn2011.aspx [Accessed 30 January 2013].

Horin, R. 2005, Through the Wire. Unpublished manuscript.

Iser, W. 1993, The Fictive and the Imaginary. Charting Literary Anthropology. John Hopkins University Press, Baltimore. 2006, 'Reception Theory,' in How to Do Theory, (ed.) W. Iser. Blackwell, Malden, MA: 57-69.

Jamieson, N. 2004, In Our Name. Unpublished Manuscript.

Jestrovic, S. 2006, Theatre of Estrangement: Theory, Practice, Ideology. University of Toronto Press, Toronto.

- 2008, 'Performing Like an Asylum Seeker: Paradoxes of Hyper-Authenticity,' Research in Drama Education, vol. 13, no. 2: 159-70.

Knaller, S. \& Müller, H. 2005, 'authentisch / Authentizität,' in Historisches Wörterbuch der Ästhetischen Grundbegriffe, (eds) K. Barck, M. Fontius, D. Schlenstedt, D. Steinwachs, \& F. Wolfzettel. Metzler, Stuttgart: 40-65.

Kolesch, D. 2005, 'Wilde Laute und mediale Resonanzen. Fremde Stimmen im Theater der Gegenwart.' Jahrbuch Deutsch als Fremdsprache 31, 208-15.

Kushner, A. R. J. 2006, Remembering Refuge : Then and Now. Manchester University Press, Manchester.

Leaky Boat, 'Synopsis.' 2011. Online, available: http://www.abc.net.au/tv/documentaries/downloads/leakyboat_synopsis.pdf [Accessed 14 July 2011].

Leggewie, C. \& Zifonun, D. 2010, 'Was heißt Interkulturalität?,' Zeitschrift für interkulturelle Germanistik, no. 1: 12-31.

Lehmann, H-T. 1999, Postdramatisches Theater. Frankfurt am Main, Verlag der Autoren. 2006, Postdramatic Theatre, (trans. \& intro.) K. Jürs-Munby. Routledge, London \& New York. 2008a, 'Theory in Theatre? Observations on an Old Question,' in Experts of the Everyday: The Theatre of Rimini Protokoll, (eds) M. Dreysse \& F. Malzacher. Alexander Verlag, Berlin: 152-67. 2008b, 'Vom Zuschauer,' in Paradoxien des Zuschauens. Die Rolle des Publikums im Zeitgenössischen Theater, (ed.) J. Deck \& A. Sieburg. Bielefeld, transcript: 21-26.

Maclean, A. 2004, 'Verbatim Theatre Inquiries,' Canberra Times, 21 October: 9.

Mamouney, D. 2002, Citizen X: Letters from Detention, the Human Stories Behind the Politics. Script. Online, available: http://www.safecom.org.au/citizenx.htm [Accessed 20 December 2011].

Marr, D. 2009, 'Who's Afraid of the “R” Word?', The Age. Online, available: http://www.theage.com.au/national/whos-afraid-of-the-r-word-20090417-aa9q.html [Accessed 15 January 2012].

Marriner, C. 2009, 'Tragedy Haunts Music,' The Sydney Morning Herald, 10 October. Online, available: http://www.smh.com.au/news/entertainment/music/tragedy-hauntsmusic/2009/10/09/1255019613354.html [Accessed 10 January 2012].

McCallum, J. 2004, 'Human Drama Lost in a Sea of Words,' The Australian, 2 April: 17. 2006, “"CMI” (“A Certain Maritime Incident”): Introduction,' Australasian Drama Studies, no. 48, April: 136-42. 2009, Belonging. Australian Playwriting in the 20th Century. Currency Press, Sydney.

Meston, R. 2004, 'A Certain Maritime Incident,' Artlook, 5 October. Online, available: http://www.artlook.com.au/article.asp?contentID=511 [Accessed 11 April 2008].

Metzger, S. 2010, Theater und Fiktion. Spielräume des Fiktiven in Inszenierungen der Gegenwart. Bielefeld, transcript.

Midwinter Pitt, V. 2011, Leaky Boat, ABC Television, 7 July.

Mumford, M. 2003. 'Verfremdung,' The Oxford Encyclopedia of Theatre and Performance, (ed.) D. Kennedy. Oxford University Press, Oxford: 1404-5.

Nolan, T. 2004, 'A Certain Maritime Incident: "Pure Theatre," The World Today, ABC Radio National.

Nickel-Bacon, I., Groeben, N., \& Schreier, M. 2000, 'Fiktionssignale pragmatisch. Ein medienübergreifendes Modell zur Unterscheidung von Fiktion(en) und Realität(en), Poetica, no. 3-4: 267-99. 
'Official Committee Hansard.' 2002, Select Committee on a Certain Maritime Incident, 5 April. Online, available: http://www.aph.gov.au/hansard/senate/commttee/s5412.pdf [Accessed 2 December 2011].

O’Mahoney, I. 2011, Go Back to Where You Have Come From, SBS Television, 21-23 June.

Paget, D. 1998, No Other Way to Tell It: Dramadoc/Docudrama on Television. Manchester University Press, Manchester.

Phillips, J. 2012, 'The "Pacific Solution" Revisited: a Statistical Guide to the Asylum Seeker Caseloads on Nauru and Manus Island,' Parliament of Australia, Department of Parliamentary Services, 4 September. Online, available:

http://parlinfo.aph.gov.au/parlInfo/download/library/prspub/1893669/upload_binary/1893669.pdf;f ileType=application \%2Fpdf [Accessed 3 January 2013].

Schmidt, D. 2001-2002, Xenophobe-Shipwreck Scene, Dedicated to the 353 Drowned Asylum Seekers who Died on the Indian Ocean, on the Morning of October 19. Online, available: http://www.documenta11.de/index.php?id=1215 [Accessed 13 July 2011].

Siegel, M. 2011, 'In Australia, Reality TV Tackles Immigration,' New York Times, 21 June. Online, available: www.nytimes.com/2011/06/22/world/asia/22iht-australia22.html?pagewanted=all [Accessed 14 July 2011].

'SIEV X Memorial. A Pictorial Report of the Memorial Held in Canberra.' 2006, RealTime, no. 76, December-January. Online, available: http://www.realtimearts.net/article/issue76/8247 [Accessed 14 July 2011].

SIEVX Survivor Accounts. 2002. Site established and maintained by M. Hutton. Online, available: http://sievx.com/articles/disaster/KeysarTradTranscript.html [Accessed 19 November 2011].

Spivak, G. C. 1976, 'Translator's Introduction,' in Of Grammatology, J. Derrida. John Hopkins University Press, Baltimore: ix-lxxxvii.

Svich, C. 2003, 'Moisés Kaufman: “Reconstructing History Through Theatre”-An Interview,' Contemporary Theatre Review, vol. 13, no. 3: 67-72.

'Terms of Reference.' 2002, Select Committee for an Inquiry into a Certain Maritime Incident. Online, available: http://www.aph.gov.au/senate/committee/maritime incident ctte/index.htm [Accessed 24 July 2010].

Thompson, J., \& Schechner, R. 2004, 'Why “Social Theatre”?' The Drama Review, vol. 48, no. 3: 11-16.

Trezise, B. 2004, 'Version 1.0 Shares the Shame,' RealTime, no. 61, June-July. Online, available: http://www.realtimearts.net/article/61/7437 [Accessed 14 January 2012].

Trioli, V. 2001, Transcript of the Hon. Peter Reith MP. Radio Interview with Virginia Trioli, Melbourne Radio 3AK, 10 October. Online, available: http://www.abc.net.au/news/howardyears/trioli_reith_2001.pdf [Accessed 24 July 2010].

UNHCR. 2012, 'Asylum Claims in Industrialized Countries up Sharply in 2011,' 27 March. Online, available: http://www.unhcr.org/4f7063116.html [Accessed 3 January 2013].

United Nations Human Development Report. 2009, Online, available: http://hdr.undp.org/en/media/HDR_2009 EN_Summary.pdf [Accessed 4 July 2010].

version 1.0. 2004a, CMI (A Certain Maritime Incident). A Performance Devised from Transcripts of the 'Children Overboard' Senate Inquiry. Performance Text. 2004b, CMI (A Certain Maritime Incident). DVD. 2012, Remixing Politics: 3 Documentary Theatre Works (CMI (A Certain Maritime Incident)/The Wages of Spi /Deeply Offensive and Utterly Untrue). Currency Press, Sydney.

'version1.0: Innovative Political Performance.' 2012, Online, available: http://www.versiononepointzero.com/index.php/about/ [Accesssed 6 October 2009].

Waldenfels, B. 1998, Grenzen der Normalisierung. Studien zur Phämenologie des Fremden 2. Suhrkamp, Frankfurt am Main.

Wake, C. 2010a, 'Verbatim Theatre Within a Spectrum of Practices,' in Verbatim. Staging Memory and Community, (ed.) P. Brown. Currency Press, Sydney: 6-8. 2010b, 'Caveat Spectator: Juridical, Political and Ontological False Witnessing in CMI (A Certain Maritime Incident),' Law/Text/Culture, vol. 4, no. 1: 160-87.

Webb, J. 2009, 'Sentences from the Archive,' Performance Paradigm, vol. 5, no. 1. Online, available: http://www.performanceparadigm.net/wp-content/uploads/2009/07/webb-final.pdf [Accessed 20 December 2012].

Weiss, P. 1971, 'Notizen zum dokumentarischen Theater,' in Rapporte 2. Suhrkamp, Frankfurt am Main: 91-104.

Weller, C. 2007, 'Trauma und Melancholie, 'in Moderne Begreifen. Zur Paradoxie eines SozioÄsthetischen Deutungsmusters, (eds) C. Magerski, R. Savage, \& C. Weller. Deutscher Universitätsverlag, Wiesbaden: 157-68. 
Williams, D. 2006, 'Political Theatrics in the "Fog of War."' Australasian Drama Studies, no. 48, April: $115-29$.

Young, S. 2009, 'Playing with Documentary Theatre: "Aalst” and "Taking Care of Baby." New Theatre Quarterly, no. 25: 72-87.

Žižek, S. 2002, Welcome to the Desert of the Real: Five Essays on 11 September and Related Dates. Verso, London \& New York. 